\title{
EVOLUCIÓN DA SITUACIÓN SOCIOLINGÜÍSTICA EN GALICIA NOS ÚLTIMOS ANOS*
}

\section{Mauro Fernández}

\section{Universidade da Coruña}

* Os cambios neste texto en relación co relatorio presentado polo autor no Seminario obxecto desta publicación son moi poucos, apenas os imprescindibles para pasar dun público presente e ouvinte a un lector distante e disperso. Engadíronse algunhas notas coa finalidade de achegar información suplementaria e para tomar en consideración os últimos datos sobre a situación das linguas en Galicia, os do IGE 2008, que aínda non foran dados a coñecer cando se realizou a primeira sesión do seminario, en decembro de 2009. 

1.

Hai xa máis de dez anos que o principal foco do meu traballo investigador está moi lonxe do galego e de Galicia. Desde que fun vivir por algún tempo a Filipinas, un poderoso feitizo deixoume atrapado e mantén o meu traballo moi apegado a aquelas afastadas terras do oriente. Só ocasionalmente teño volto ás cousas do galego porque non podía desatender as xentís invitacións puntuais que me fixeran, como tampouco podía deixar de atender esta de agora, coa que me honran os organizadores deste Seminario. Hónranme polo tema que me encomendaron, que tan ben ou mellor ca min podería desenvolver algún deles, e hónranme por contar comigo neste momento tan especial que estamos a vivir en relación coas linguas en Galicia.

Unha parte importante da inquietude destes últimos meses procede do diagnóstico máis recente ${ }^{1}$ sobre a situación sociolingüística, que dá por perdidas as vantaxes que lle deparaba ao galego o feito de ser a lingua maioritaria de Galicia. A mediados do pasado mes de marzo ${ }^{2}$, os xornais sorprendéronnos con titulares que alertaban sobre un forte retroceso do uso do galego nestes últimos anos, como estes: «solo el 25\% de los habitantes de las ciudades usa habitualmente el gallego» en El País, ou «el gallego está en el peor momento de su historia» en $\mathrm{La}$ Voz de Galicia, e outros polo estilo ${ }^{3}$; mesmo en Asturias destacouse que «el gallegu ya non yé l'idioma más emplegáu en Galicia».

Estes titulares sintetizaban unhas declaracións do voceiro da Mesa pola Normalización Lingüística, motivadas pola publicación do volume II do novo Mapa sociolingüistico de Galicia, que acababa de aparecer silandeiramente.

\footnotetext{
1 «Máis recente» refírese á data da intervención do autor no seminario. Véxase a nota anterior.

${ }^{2}$ Refírese a marzo de 2009.

3 Velaí algúns máis. La Opinión: «Una cuarta parte de los gallegos tiene como lengua habitual sólo el castellano». O Faro de Vigo: «El número de personas que sólo usa castellano se duplicó en una década».
} 
O volume trae desde logo malas novas para o galego, moi malas. Son tamén noticias inesperadas, desde as expectativas que nos forxaramos a partir dos datos do primeiro Mapa sociolingüístico de Galicia, baseado en case 39000 entrevistas feitas no ano 1992 (en diante, MSG-92). A diferenza entre os datos sobre uso do galego naquel primeiro Mapa e os deste de agora (en diante MSG-04), baseado en 9309 entrevistas feitas no ano 2004, é moita. É tan grande esa diferenza que non nos explicamos, ou polo menos eu non me explico, como foi posible que non nos decataramos xa de que se estaba a dar ao noso arredor esa fuxida en desbandada do galego, en tan só doce anos, sen necesidade de que unha enquisa viñese a descubrírnolo, e sen que o descubrira antes ningunha das outras enquisas que se fixeron, nin tampouco os Censos de poboación, nos que se sustenta unha boa parte do diagnóstico que serve de fundamento ao Plan de normalización da lingua galega. A partir dos censos, máis ben tiñamos a impresión contraria: que o uso do galego se estabilizara e que había mesmo indicios de que podía estar remontando. E os censos, como é ben sabido, son a mellor ferramenta da que dispomos para aproximarnos á realidade demográfica.

Dou por ben establecido que as estimacións estatísticas contidas no primeiro Mapa se axustaban moito á situación real da lingua naquel momento, o ano 1992, na medida en que o permite un traballo cuantitativo deste tipo ${ }^{4}$. Esta seguridade miña pode parecer arrogancia xa que, como é ben sabido entre os sociolingüistas, tiven o privilexio de dirixir cientificamente aquel traballo. Pero a miña seguridade procede non só de que me considero «letrado» na sociolingüística cuantitativa e nas súas miudezas, senón tamén da crítica internacional moi favorable que mereceu o traballo e - sobre todo- das enquisas posteriores que, dirixidas por xente non menos capaz, confirmaron esas estimacións, como veremos máis adiante.

O novo mapa, en cambio, dá uns resultados que son, na miña opinión, moi improbables, pois desvíanse moito dos demais traballos, tanto dos anteriores como dos contemporáneos 5 . E por iso, antes de asumir como certa a desbandada da que nos informa, convén sometelo a un rigoroso exame e asegurarse de que non hai nel eivas que limiten severamente a fiabilidade destas novas estimacións.

${ }^{4}$ Unha medida, xa que logo, que ten as limitacións inherentes a este tipo de enfoque cuantitativo, que necesariamente debe ser complementado con outro tipo de aproximacións.

${ }^{5}$ Agora, tras facerse públicos os resultados do IGE 2008, poderiamos engadir que tamén se distancian dos posteriores. 
Intento así dar cumprimento a un dos obxectivos deste encontro, tal como se explicou na súa presentación á prensa, o de aclarar, se son capaz, as contradicións entre as diversas fontes e datos dispoñibles.

Os diagnósticos das situacións sociolingüísticas son sempre complexos, con diversas facetas que non camiñan á par. Pero as contradicións que nos teñen perplexos non están en todas as facetas. Creo interpretar ben o sentir dos organizadores se me limito ao aspecto que motivou os titulares de escándalo. Realmente urxe saber se esa desbandada no uso do galego que indican os resultados recentes do Seminario de Sociolingüística se está a dar ou non. Eses resultados están a entrar xa nos discursos sobre a lingua como se fosen as verdades máis patentes e incontrovertibles. Non só nos discursos dos que viven esta situación con fonda preocupación e angustia, senón tamén nos daqueles que, desde outras sensibilidades lingüísticas e culturais, consideran que algunhas das medidas que se tomaron para incentivar o uso do galego atentan contra a liberdade. Lemos, por exemplo, nun artigo dun socio de Galicia Bilingüe, un resumo dos resultados do novo mapa, no que se pregunta «¿Cuál es la realidad?». A resposta, no esencial, recóllese nesta frase: «la estimación final es que el uso del gallego en Galicia es minoritario respecto al castellano». E péchase así, con redundante contundencia: «Los datos son datos, y no se discuten, sino que se comprueban». E todo iso avalado nada menos que pola Real Academia Galega, como ben recorda o autor. Pois ben, comprobemos, logo, os datos e as fontes.

2.

Comezarei por explicar as razóns para a miña suspicacia acerca dos novos datos da RAG.

O primeiro Mapa sociolingüistico contiña datos sobre o uso do galego que permitían unha visión relativamente optimista da situación da lingua, e que cimentaban os discursos baseados na noción de «maioría». Por exemplo, o de que era a lingua habitual do $68,6 \%$ da poboación. Este dato desmentía os discursos catastrofistas que xa anticipara Murguía cando escribira en 1865 aquilo de «amanecen para el gallego días de verdadera desgracia», e que desde entón se veñen repetindo de cando en vez. Unha lingua falada como habitual por case o $70 \%$ da poboación parecería que está a salvo de calquera perigo inmediato. 
Pero reparando nos datos de certos sectores da poboación, a percepción podía resultar ben diferente. No grupo dos máis novos, os que tiñan daquela, no ano 1992, entre 16 e 19 anos, os falantes habituais do galego xa non eran maioría, e estaban bastante por debaixo da metade: eran o 40,6\%.

E se nos fixamos neste mesmo grupo dos máis novos, pero nas cidades, tan só o $12,9 \%$ tiñan o galego como lingua habitual. E peor aínda: nos casos menos favorables, non chegaban ao $8 \%$ os mozos e mozas entre 16 e 19 anos que falaban habitualmente galego en Ferrol ou na Coruña.

$\mathrm{Na}$ figura 1 pode apreciarse como se distribuía en 1992 o uso da lingua segundo a idade: canto máis novos eran os individuos, en menor medida tiñan o galego como lingua habitual.

- Figura 1. Galego como lingua habitual segundo a idade (MSG-92)

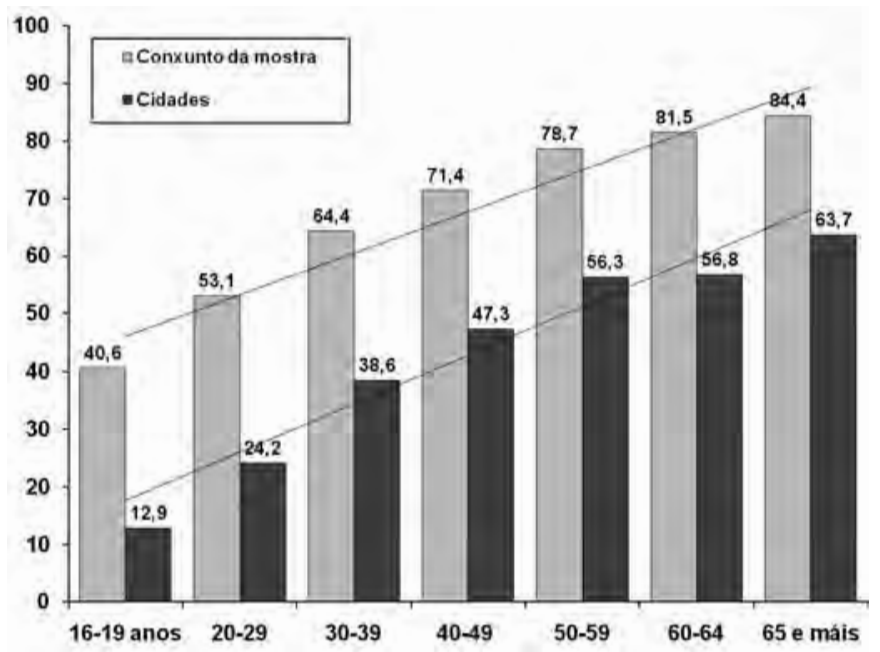

Esta distribución por idades suxire unha imaxe moito menos confortable que a que nos dá ese case $70 \%$ de usuarios habituais no conxunto da poboación; e peor aínda se nos fixamos nas cidades, que adoitan ser o inicio e o modelo dos cambios culturais. Se comparamos cada parella de columnas adxacentes podemos ver canto se distancian as cidades do conxunto da mostra no uso habitual do galego, pero non se diferencian na pauta: as liñas de tendencia son case paralelas. 
O volume primeiro do MSG-92 trataba da lingua inicial e nela observábase tamén a mesma distribución por idades, tanto máis negativa para o galego canto máis novos eran os individuos. Cando se publicou ese primeiro volume, no ano 1994, a revista Luzes de Galiza recolleu as dúas perspectivas baixo o título de «A lingua, morre ou non?». A perspectiva pesimista, que focalizaba a distribución descendente a través da idade, viña da man de Antón Santamarina, quen titulou así a súa contribución: «O galego no precipicio. Meditacións a propósito do MSG». Na posición oposta, focalizando os datos para o conxunto de Galicia, Xesús Ferro púxolle á súa contribución este título: «O galego resiste moi ben».

As dúas perspectivas tiñan a súa parte de razón, pero ningunha delas a tiña toda; ningunha esgotaba a realidade, como sucede tipicamente nas situacións de cambio social. E os datos, non só os lingüísticos, indicaban que estabamos inmersos nunha dinámica de profundo cambio cultural que estaba afectando, entre outras cousas, aos usos lingüísticos tradicionais e ao desenvolvemento de novas prácticas comunicativas e de novas lealdades lingüísticas.

\section{1.}

Antes de continuar, cómpre deixar ben claro que con esta distribución decrecente por idades, mesmo no caso de que se conxelase a dinámica de cambio, unha enquisa feita en 2004 ou calquera que se fixese no futuro terían que resultar necesariamente en porcentaxes cada vez máis baixas de uso do galego, ao ir desaparecendo do teatro da vida as xeracións que máis o utilizan, as da dereita da Figura 1. Sería así até pasados aproximadamente uns cincuenta anos.

Imaxinemos que xa pasaron eses anos e que estamos en 2042, cunha conxelación do cambio de lingua desde 1992, co mesmo peso dos diferentes tipos de hábitat, e aparcada a catástrofe demográfica cara á que semella que nos encamiñamos en Galicia. Dados todos eses supostos imaxinarios, teriamos nas columnas de máis á dereita da figura 1 aos que agora están nas de máis á esquerda, pois, con cincuenta anos máis enriba, habería tempo que xa terían deixado de ser os máis novos e estarían empezando a pertencer ao grupo dos máis vellos. Imaxinemos tamén, para simplificar o cálculo, que coa medicina biolóxica e as novidades que o futuro nos depare todos viven até os oitenta e nove anos, ninguén morre antes nin vive máis tempo. Logo, nese grupo dos máis vellos estarían comprendidos todos os que no ano 1992 tiñan menos de corenta anos, é dicir, 
os das tres primeiras columnas. Neste escenario ficticio, a porcentaxe de usuarios habituais do galego nese grupo dos máis vellos sería o 55,2\%. E posto que o que estamos a imaxinar é unha conxelación do cambio, teriamos a mesma porcentaxe nos seguintes grupos de idade, cunha moi idealizada estabilización total, como amosa a figura 2.

- Figura 2. Escenario máis favorable aos 50 anos do MSG-92 (cambio conxelado)

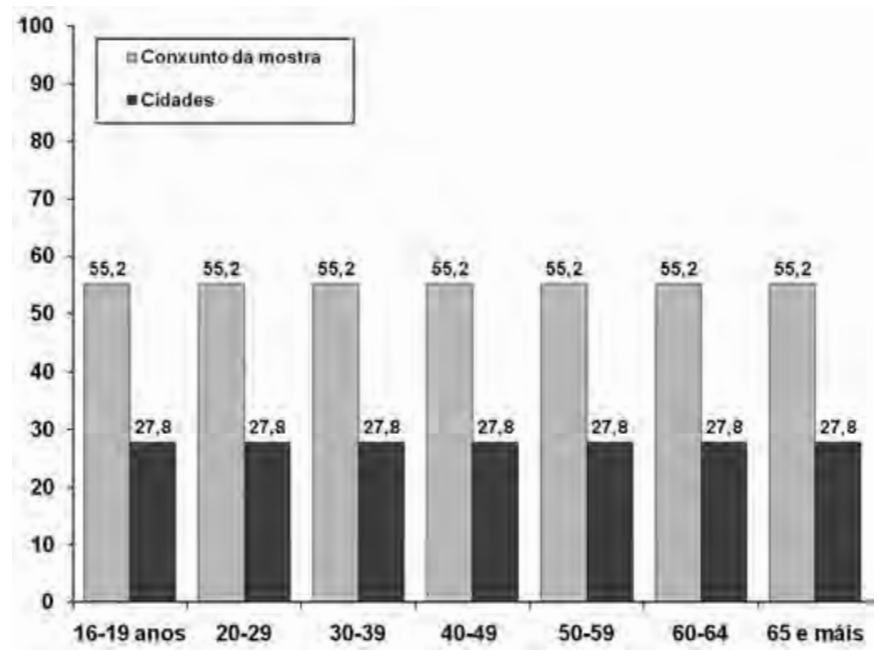

Esta situación hipotética permitiría manter aínda a mediados do século XXI discursos baseados no feito de ser o galego a lingua máis falada pola maioría da poboación. Nas cidades, esa conxelación resultaría nun 27,8\% de galegofalantes habituais.

\section{2.}

Veñamos máis cerca no tempo e tratemos agora de imaxinar cal sería o peor escenario posible en 2004 -que é o ano en que se recolleron os datos do segundo mapa, doce anos despois do primeiro-, atendendo tan só ao cambio interxeracional, é dicir, a falla de transmisión do uso do galego ás xeracións máis novas. O peor de todo sería que non falase habitualmente galego ningún dos que veñen despois daqueles que eran os máis novos no MSG-92. Para simular eses datos temos, pois, que incrementarlles á idade doce anos a todos os individuos da mostra representada na figura 1, desprazando cada columna un pouco á dereita. Imos prescindir, pola 
dereita do gráfico, dos que con este incremento na idade terían más de oitenta e cinco anos, para que o peso deste grupo dos máis vellos no conxunto da mostra sexa equivalente ao que tiñan na poboación real no ano 2004.

E para completar a simulación enchemos o lugar que van deixar á esquerda os máis novos con mozos e mozas que non teñan, ningún deles, o galego como lingua habitual.

- Figura 3. Peor escenario posible aos 12 anos do MSG-92 (poboación até 85 anos)

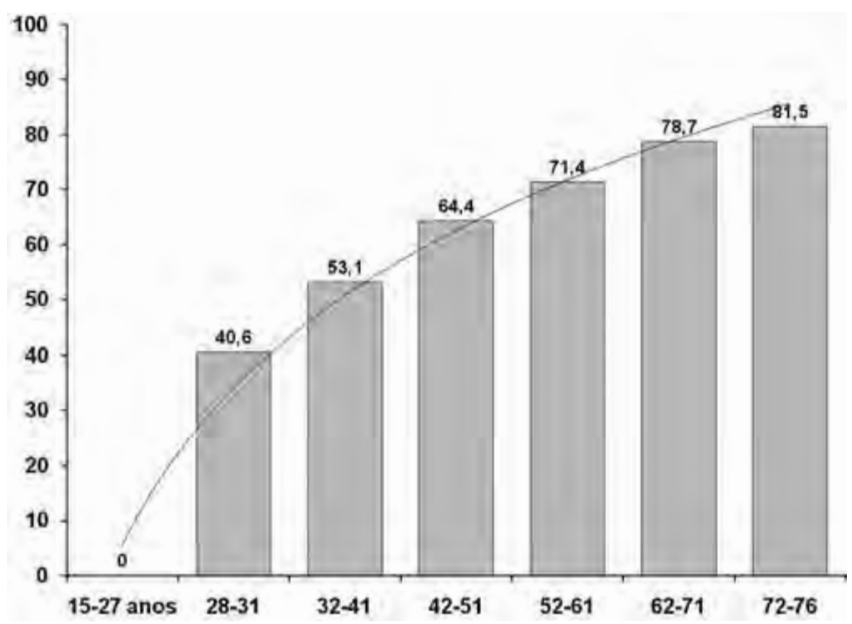

Teriamos logo o que amosa a figura 3, unha situación en que o galego desaparecería por completo nos máis novos. Pero aínda así, no conxunto da poboación, os usuarios habituais do galego seguirían a ser a maioría, o 53,1\%.

Insisto en que este escenario que estamos a imaxinar toma en conta só o cambio interxeracional, un cambio enorme, a cero nos máis novos, pero non contempla ningún cambio intraxeracional, é dicir, asumimos nesta ficción unha estabilidade total, de xeito que ningún dos que falaban habitualmente galego no ano 1992 deixou de falalo nos doce anos seguintes. Nin tampouco os que falaban castelán.

Ninguén, naturalmente, esperaría esa perda total do uso do galego nos máis novos en tan pouco tempo. Pero este escenario ficticio vainos ser de utilidade como punto de referencia para explicar a miña incredulidade ante o que nos conta o MSG-04, que recollemos na última fila da táboa 1: 
- Táboa 1. O MSG-92 fronte ao MSG-04

\begin{tabular}{lll} 
Enquisa & $\begin{array}{l}\text { Falan habitualmente } \\
\text { en galego \% }\end{array}$ & $\begin{array}{l}\text { Falan habitualmente } \\
\text { en castelán } \%\end{array}$ \\
\hline MSG-92 & 68,6 & 31,4 \\
\hline $\begin{array}{l}\text { Peor escenario imaxinable } \\
\text { en } 2004 \text { (transmisión nula }\end{array}$ & & \\
aos máis novos) & 53,1 & 46,9 \\
\hline MSG-04 & 38,4 & 61,6 \\
\hline
\end{tabular}

En vez do 53\% de usuarios habituais do galego que habería nese 2004 ficticio co peor escenario de transmisión imaxinable, cun uso nulo do galego nos máis novos, resulta que no 2004 da «realidade» tal como nola conta a Real Academia Galega temos aínda moito menos: só unhas décimas por riba do 38\%. Se isto fose certo, entón, a partir de agora mesmo, ningún discurso sobre o galego podería sustentarse xa na noción de ser a lingua habitual da maioría da poboación.

\section{3.}

Días despois da publicación dos titulares aos que me referín ao inicio, algún xornal matizou que as mostras dos dous mapas son diferentes en aspectos esenciais. A diferenza de deseño máis importante consiste en que a mostra do MSG-92 representaba a toda a poboación maior de dezaseis anos, sen límite superior. A do MSG-04, en cambio, ademais de baixar un pouquiño o límite inferior aos quince anos, ten un límite superior nos cincuenta e catro anos ${ }^{6}$. Moitos de nós, pois, non estariamos representados nesta mostra $^{7}$ : en concreto, todos os que estamos por riba da liña grosa superior, e tamén os que están por debaixo da inferior, na figura 4, que presenta a distribución da idade da poboación galega no ano 2004 segundo o Instituto Nacional de Estadística.

\footnotetext{
${ }^{6}$ Hai algunha outra diferenza entre as dúas mostras, de menor entidade, como os cortes de idade tomados en consideración para a estratificación.

${ }^{7}$ Isto non ten unha xustificación doada. A ofrecida a un xornal polo director do traballo non me parece de recibo: «no vamos a normalizar a la gente de 80 años», declarou o director a un periodista de El País (21 de marzo de 2009). Deixando a un lado a idea implícita, que non compartimos, de que haxa que normalizar as persoas, desde a perspectiva do coñecemento da situación sociolingüística e mesmo desde a da normalización da lingua, é obvio que os que temos máis de 54 anos somos tan importantes como calquera outro.
} 
- Figura 4. Distribución da idade da poboación de Galicia en 2004

Poboación por sexo e idade, 2004. Galicia

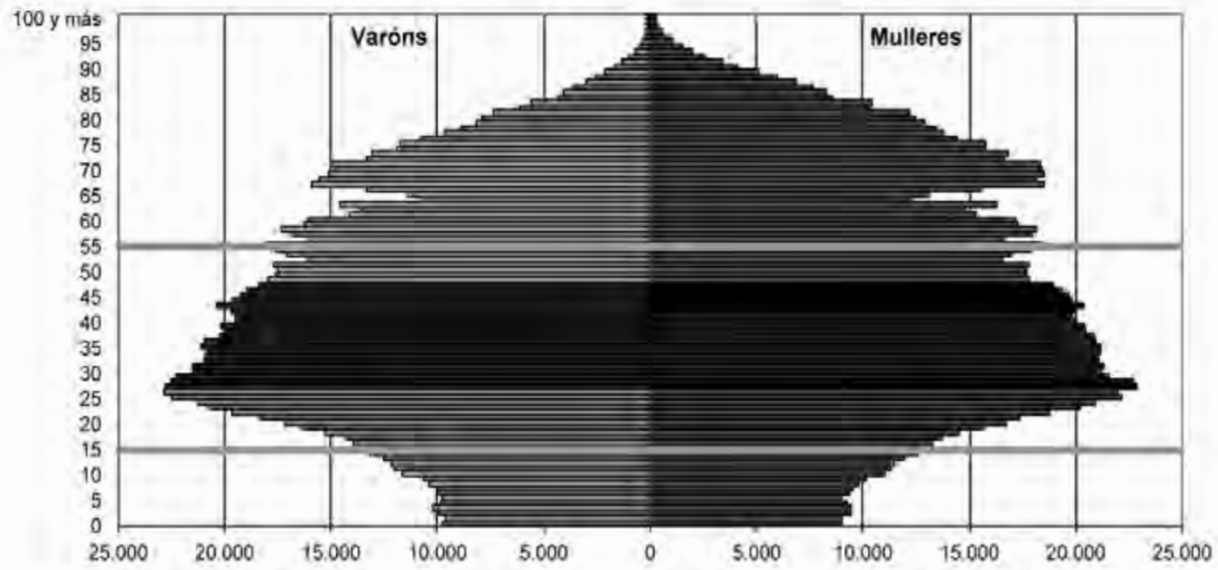

Fonte: INE: INEBASE: Revisiön đo Padrón muniçpal a 1 de xaneiro de 2004, (Liñas grosas engadidas)

Conscientes do problema que representa o diferente ámbito das mostras, os autores do mapa de 2004 reanalizaron os datos do de 1992, prescindindo neste dos maiores de cincuenta e catro anos; e para axustar máis a comparación, prescindiron tamén dos de quince anos da súa propia mostra, para ter así dúas mostras equiparables na idade, desde os dezaseis anos até os cincuenta e catro. Tras esa mutilación das mostras —en especial da de 1992- de cara á comparabilidade, os resultados da comparación serían os que se amosan na táboa 2:

- Táboa 2. MSG-92 vs. MSG-04, tras axustar a idade

\begin{tabular}{lll} 
Enquisa & $\begin{array}{l}\text { Falan habitualmente } \\
\text { en galego } \%\end{array}$ & $\begin{array}{l}\text { Falan habitualmente } \\
\text { en castelán } \%\end{array}$ \\
\hline MSG-92 & 61 & 39 \\
\hline MSG-04 & 38,9 & 61,1 \\
\hline
\end{tabular}

A aparente perda resulta ser agora de vinte e dous puntos porcentuais, en vez dos trinta que viamos antes na táboa 1 . Axustadas as idades ao mesmo límite superior (54 anos) e inferior (16 anos), do $61 \%$ que falaban habitualmente gale- 
go en 1992 pasariamos a tan só un 39\% escaso. Dicimos «aparente perda» porque, como imos ver, hai algunhas complicacións que dificultan dar por válido este dato, e con el moitos dos que contén o MSG-04.

\section{4 .}

No apartado 2.2 simulabamos un escenario ficticio para o ano 2004 (doce anos despois do MSG-92), con límite superior de idade nos oitenta e cinco anos, con transmisión interxeracional nula no uso do galego, pero sen perda intraxeracional, é dicir, conservando cadaquén o uso do galego que facía no ano 1992. Agora ben, como sería ese escenario se puxésemos o límite superior de idade onde o pon o novo mapa, en vez de poñelo nos oitenta e cinco anos? Isto é, deberiamos poñer o límite da nosa simulación nos que tiñan cincuenta e catro anos en 1992, e que, xa que logo, tiñan en 2004 sesenta e seis, doce anos máis. Noutras palabras, se prescindimos dos moitos falantes de galego que hai nas dúas columnas da dereita da figura 3 (máis atrás) e tamén dunha parte dos da columna seguinte, e con cero usuarios do galego nos menores de vinte e oito anos, asegurándonos de que lles damos a estes o peso real que tiñan no conxunto da poboación de 2004. Ese escenario de pesadelo para o futuro do galego está representado na figura 5.

- Figura 5. Peor escenario posible aos 12 anos do MSG-92 (poboación até os 66 anos)

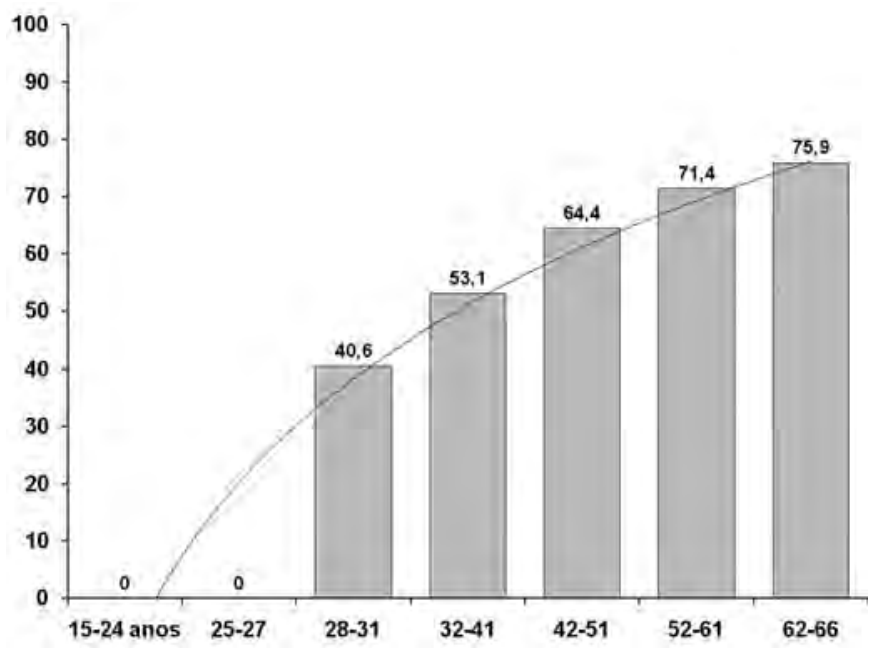


Pois ben, aínda que custe traballo crelo, os datos serían aínda mellores para o galego ca os que acaba de facer públicos a Academia. Fronte ao 38,9\% de falantes habituais de galego que vemos na última fila da táboa 2 (máis atrás), nesta simulación habería un 44,2\%.

E cal sería o panorama se en vez do cero que imaxinamos nas dúas columnas da esquerda da figura 5 puxésemos as porcentaxes obtidas no MSG-04 para eses tramos de idade? A figura 5 transformaríase nestoutra:

- Figura 6. Proxección a 12 anos do MSG-92

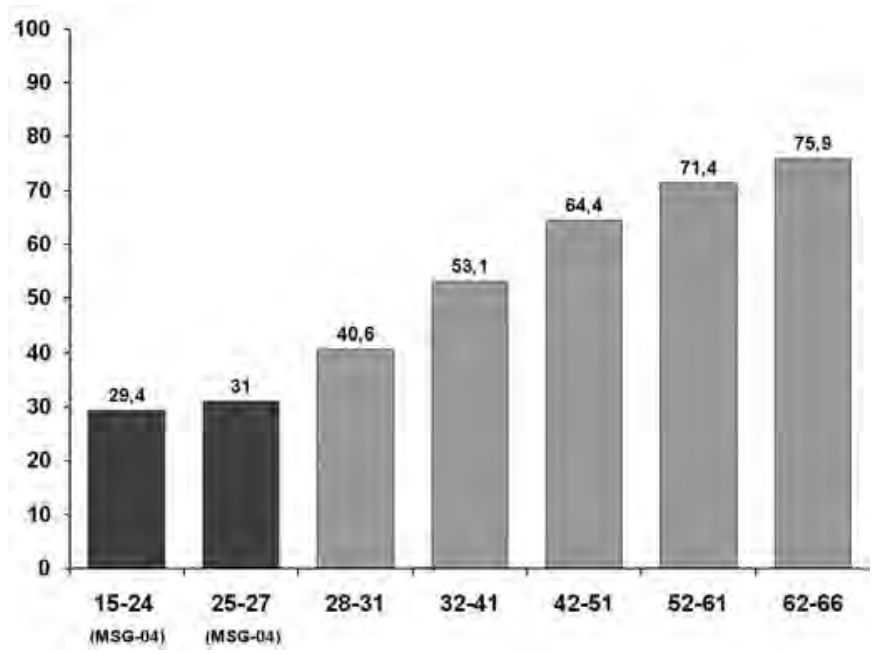

Coa diferenza de grises nas columnas do gráfico só quero alertar sobre a diferente procedencia dos datos. Os das dúas columnas da esquerda proceden da sondaxe de 2004, mentres que os outros proceden da de 1992 . O peso de cada columna en gris claro no conxunto da mostra é o que tiñan eses tramos de idade no censo de 1991, e o peso de cada columna en gris escuro é o que tiñan eses tramos de idade no censo máis recente, o de 2001. Pois ben, nesa proxección a 12 anos, máis realista ca as anteriores, o panorama global sería moito máis favorable ao galego ca o que nos ofrece o novo mapa da Academia, como amosamos na táboa 3 . 
- Táboa 3. Uso habitual das linguas (MSG-04 vs. proxección a 12 anos do MSG-92)

\begin{tabular}{lll} 
Enquisa & $\begin{array}{l}\text { Falan habitualmente } \\
\text { en galego \% }\end{array}$ & $\begin{array}{l}\text { Falan habitualmente } \\
\text { en castelán } \%\end{array}$ \\
\hline MSG-04 & 38,9 & 61,1 \\
\hline $\begin{array}{l}\text { Proxección realista para 2004, } \\
\text { a partir dos datos do MSG-92 }\end{array}$ & 52,4 & 47,6 \\
\hline
\end{tabular}

Esta nosa nova simulación, menos fantasiosa ca as de antes, amosa que o galego sería aínda a lingua habitual maioritaria, con algo máis do $52 \%$ de falantes habituais ${ }^{8}$ na poboación até os cincuenta e catro anos, máis de trece puntos por riba do que nos di o MSG-04.

\section{5 .}

Que se deduce desta serie de escenarios simulados? Teremos que facerlle máis caso a unha simulación que aos datos «reais» que nos fornece a Academia a través do seu Seminario de Sociolingüística? Non nos precipitemos, pero reparemos nun aspecto importante: o que a última simulación nos indica é que, de seren correctos os datos e as análises do MSG-04, esa enorme perda de vinte e dous puntos porcentuais no uso do galego desde 1992 (véxase a táboa 2 máis atrás) non sería toda ela interxeracional. Tería que terse dado ademais unha moi importante perda intraxeracional. Noutras palabras, esa caída no uso do galego non se debería só a que os individuos dos grupos de idade máis novos na enquisa de 2004, os das dúas columnas da esquerda na figura 6, o usen menos ca os outros; sería necesario ademais que unha parte importante dos individuos das outras columnas, en especial aqueles que están representados en ambas as dúas mostras, tivesen abandonado o uso preferente do galego nos doce anos transcorridos entre as dúas enquisas.

Os representados nas dúas mostras son os individuos que na enquisa MSG-04 teñen vinte e oito ou máis anos, pois tiñan en 1992 como mínimo dezaseis anos,

${ }^{8}$ Talvez unhas décimas menos, pois á columna dos que teñen de 25 a 27 anos na figura 6 atribuímoslle o valor que no MSG-0 4 corresponde a todo o tramo de 25 a 34 anos. Sen dispor de acceso ao arquivo de datos do MSG-04, usando só os datos publicados, son inevitables estas pequenas imprecisións, que non afectan ao esencial da análise. 
que era o límite inferior de idade para seren incluídos na enquisa do primeiro Mapa. Calquera diferenza, pois, entre os dous mapas para a parte da poboación representada en ambos deberase ao cambio intraxeracional, isto é, a que houbo individuos que deixaron de falar habitualmente o galego (ou o castelán) durante os doce anos transcorridos entre as dúas sondaxes.

Tendo isto en conta, para explicármonos os resultados do segundo Mapa teriamos que admitir que esa perda intraxeracional tivo que ser moi importante, abofé máis importante cá interxeracional: dos vinte e dous puntos porcentuais de perda do uso habitual do galego que amosa o mapa de 2004 en relación co de 1992 (véxase táboa 2 máis atrás), resulta que quince teñen que proceder dos individuos representados nas dúas mostras, como se recolle na táboa 4 .

- Táboa 4. Suposta perda intraxeracional

\begin{tabular}{lll} 
Enquisa & $\begin{array}{l}\text { Falan habitualmente } \\
\text { en galego \% }\end{array}$ & $\begin{array}{l}\text { Falan habitualmente } \\
\text { en castelán \% }\end{array}$ \\
\hline $\begin{array}{l}\text { MSG-92. Poboación de 28 a } \\
54 \text { anos (en 2004) }\end{array}$ & 56,4 & 43,6 \\
\hline $\begin{array}{l}\text { MSG-04. Poboación de 28 a } \\
54 \text { anos }\end{array}$ & $41,3^{9}$ & 58,7 \\
\hline
\end{tabular}

Noutras palabras, para que os datos do novo Mapa sexan cribles, temos que asumir que de cada cen individuos que no ano 2004 tiñan entre vinte e oito e cincuenta e catro anos, quince cambiaron o uso habitual do galego polo do castelán nos doce anos precedentes.

Todo é posible, naturalmente. Pero esta mudanza é demasiado importante como para non térmonos decatado dela sen necesidade desta enquisa de 2004 e, sobre todo, como para que non fose detectada por outras enquisas, nin tampouco polos Censos de poboación. Imaxinemos calquera outra conduta que afectase ao quince por cento da poboación: adornarse con toucado de plumas,

${ }^{9}$ Estimación feita atribuíndolle ao grupo entre 28 e 34 anos as porcentaxes que se indican no volume II do MSG-04 para a totalidade do grupo entre 25 e 34 anos. A diferenza co que obteríamos tendo acceso aos microdatos non pode ser moi grande, só unhas poucas décimas. 
por exemplo, ou converter o inglés en lingua habitual de intercambio social dentro de Galicia, e pensemos se o fenómeno podería pasarnos tan desapercibido.

3.

Xa que nada é imposible, como acabamos de dicir, logo tamén é posible que malia o apoio que lle dá o nome da Real Academia Galega, esta enquisa de 2004, que nos vén a descubrir o que ningunha das outras nin o censo foron capaces de descubrir, teña problemas de análise, ou problemas na mostra, ou ambas as cousas, que desvirtúen as estimacións que fai sobre a poboación real.

Voume limitar aos problemas da mostra, pois outros que hai non teñen relevancia para o asunto que aquí tratamos (aínda que si a teñan para outros). Os resultados que nos interesan neste caso preséntanse como porcentaxes, polo que non se ven afectados polas inadecuacións que poida haber na análise cando se aventura máis alá das táboas de continxencia.

Nalgunha das críticas recollidas grosso modo pola prensa apuntábase á enorme diferenza de tamaño das mostras, e ao feito de que na do ano 2004 predominaran os individuos urbanos, mentres que na de 1992, mesmo contando cunha representación urbana máis nutrida, predominaban os individuos non urbanos. Pero ningunha desas diferenzas ten demasiada importancia. En ambos os casos hai en realidade varias mostras, que se combinan ou se agregan cando se trata de obter a imaxe global de Galicia (ou outras intermedias). Para facer esta combinación é necesario ponderar as diferentes submostras para darlle a cada unha delas o peso que lle corresponde, que terá que ser equivalente ao que teña a poboación representada no conxunto de Galicia. Así que, se temos demasiadas entrevistas procedentes do ámbito urbano, dámoslles ás de cada cidade o peso que lle corresponda a esta no conxunto de Galicia, e o mesmo se o exceso é nas entrevistas rurais.

Hai algúns problemas técnicos, e tamén de lóxica subxacente, nisto da ponderación nos que tampouco vou entrar: direi só que non é o mesmo reducir o peso dun sector da mostra porque ten máis individuos dos que lle corresponden — práctica normal e recomendable —, que aumentar o peso dun sector insuficientemente representado e cunha marxe de erro importante, práctica que é contraproducente e que debería evitarse. Pero deixarei aquí este fío. 
En canto ao tamaño, as 9309 entrevistas do ano 2004 constitúen unha mostra suficiente, se non se pretende o estudo separado e fiable de tantas zonas como as que se estudaron en 1992.

Se a mostra do MSG-04 ten algún nesgo será, pois, por razóns diferentes do tamaño ou do predominio nela do hábitat urbano (no suposto, obviamente, de que a ponderación estea ben feita, e que as enquisas dos diversos tipos de hábitat sexan suficientes).

Sen acceso directo ao arquivo de datos, a detección por parte dos lectores de posibles problemas na mostra só se pode inferir dos datos publicados, que en moitos traballos son insuficientes para descubrilos. Neste caso, por fortuna, son suficientes: partindo dos marxinais de diversas táboas, temos abundantes indicios que apuntan a que a mostra ten problemas importantes, que pola súa índole afectan a case a totalidade dos resultados obtidos.

4.

Un nesgo ben notorio é o que hai no nivel de estudos dos membros da mostra. A asociación entre o uso do galego e o nivel de estudos xa quedou debidamente probada no MSG-92, e non hai indicios na sociedade de que teña cambiado de xeito importante: como regra xeral, canto máis alto é o nivel de estudos, menor é o uso habitual do galego. No MSG-04 próbase de novo esa asociación. Pero se nos fixamos na distribución dos estudos na mostra total do MSG-04, hai algo que chama atención: o grupo máis numeroso é o dos que teñen estudos universitarios, que case duplican aos que só teñen a ESO, triplican aos que teñen bacharelato, etc., como se pode ver na táboa 5, que reproduce unha parte da 2.1 (páxina 247) do Anexo 2 do segundo volume do Mapa, «Táboas de distribución da mostra» ${ }^{10}$ :

${ }^{10}$ Chama tamén a atención que a suma dos marxinais non dea sempre o número total de enquisas, mesmo naqueles casos en que non debería haber respostas en branco, como na idade ou no sexo. Neste caso, a suma de todos os tipos de estudos, incluídos os que non teñen ningún, non dá 9309, senón 9295 (sen ponderar, que baixan a 9280 tras ponderar por tipo de municipio). 
- Táboa 5. Reprodución parcial da táboa 2.1 do Anexo do MSG-04

\begin{tabular}{ll} 
Estudos & Total \\
\hline Sen estudos & 117 \\
\hline Primarios & 1491 \\
\hline ESO & 1676 \\
\hline FP & 1733 \\
\hline Bacharelato & 1088 \\
\hline Universitarios & 3190 \\
\hline
\end{tabular}

A porcentaxe dos que teñen estudos universitarios na mostra total de Galicia, tras a ponderación pertinente para corrixir o desequilibrio entre as diferentes mostras parciais, é do $31,1 \%{ }^{11}$. Moito nos parece: Galicia non ten desde logo a fama de ser unha Comunidade cunha elevada porcentaxe de titulados universitarios. Deberiamos mellor fiarnos nisto do que nos diga o último Censo de poboación, o do ano 2001, só tres anos anterior á enquisa do MSG-04, xa que en tres anos non podería variar moito a porcentaxe de xente con estudos universitarios. Pois ben, no Censo, filtrados os datos para axustarse aos límites de idade do MSG-04, de 15 a 54 anos, resulta que os que tiñan estudos universitarios eran menos da metade dos que hai na mostra do Mapa; eran tan só o 14,43\%. Aí temos xa un nesgo enorme: o grupo que menos uso fai do galego ten un exceso de representación na mostra, dezasete puntos porcentuais máis do que lle correspondería.

Este peso excesivo do grupo con estudos universitarios é unha constante en todas as mostras parciais que, agregadas, constitúen a mostra xeral, como se pode apreciar na táboa 6 :

${ }^{11}$ Sen ponderar, sería o $34,3 \%$. 
- Táboa 6. Poboación entre 15 e 54 anos con estudos universitarios (Censo 2001 vs. MSG-04)

\begin{tabular}{lll} 
Tamaño do municipio & Censo 2001 & MSG-04 \\
\hline Menos de 5000 hab. & 7,9 & 22,0 \\
\hline De 5000 a 10000 hab. & 9,1 & 25,7 \\
\hline De 10000 a 20000 hab. & 10,3 & 27,6 \\
\hline De 20 000 a 50 000 hab. & 11,8 & 29,7 \\
\hline Máis de 50 000 hab. & 21,7 & 39,9 \\
\hline Toda Galicia & 14,4 & 31,1 \\
\hline
\end{tabular}

Nos municipios de máis de 50000 habitantes, o Censo de 2001 indica que hai un $21,7 \%$ con estudos universitarios, falamos sempre da poboación que non pasa dos 54 anos; na mostra do mapa hai case o duplo. E no resto dos municipios hai case o triplo do que ocorre na poboación real.

Isto é algo certamente asombroso. E, se vemos por separado cada unha das sete cidades, na táboa 7, confirmamos que o peso excesivo do grupo dos que teñen estudos universitarios dáse en todas elas:

- Táboa 7. Poboación urbana entre 15 e 54 anos con estudos universitarios (Censo 2001 vs. MSG-04)

\begin{tabular}{lll} 
Cidades & Censo 2001 & MSG-04 \\
\hline A Coruña & 24,4 & 38,4 \\
\hline Ferrol & 20,3 & 35,0 \\
\hline Santiago & 27,5 & 54,2 \\
\hline Lugo & 22,5 & 41,6 \\
\hline Ourense & 21,0 & 35,2 \\
\hline Pontevedra & 20,5 & 43,1 \\
\hline Vigo & 18,3 & 34,8 \\
\hline
\end{tabular}

En Santiago de Compostela, máis da metade da mostra ten estudos universitarios, o 54\%, o dobre do que sucede na realidade; e así nas outras cidades. Ninguén que coñeza ben o concello de Pontevedra dará por bo que haxa nel un $43 \%$ de persoas con estudos superiores. 
Unha parte pequena deste exceso, arredor de dous ou tres puntos, pode deberse á diferente formulación da pregunta. No Censo rexístrase o nivel máximo de estudos rematados; no MSG-04, en cambio, recóllese o nivel máximo de estudos iniciados, aínda que non se acabasen. Pero, incluso se tomamos en consideración os que abandonaron a universidade antes de rematar, parece evidente que no MSG-04 hai unha representación excesiva dos que posúen estudos universitarios, que son os que menos usan o galego, e unha representación bastante deficitaria dos que só teñen estudos primarios, que son os que máis usan o galego. Unha mostra así non pode dar estimacións realistas sobre nada que teña que ver co galego.

Esta distribución tan nesgada dos estudos debería ter repercusión noutras variables, como no tipo de ocupación. E iso é o que en efecto sucede, como imos ver no punto seguinte.

5.

$\mathrm{Na}$ enquisa do MSG-04 utilizouse a Clasificación Nacional de Ocupacións (CNO), dispoñible desde 1994. Nela divídense as profesións en dez grandes grupos, numerados do cero ao nove. Cada un deles consta de varios subgrupos, que levan dous díxitos. Estes pola súa vez conteñen outros subgrupos, de tres díxitos, que conteñen outros de catro díxitos. A clasificación completa ten 784 liñas. Posto que é tamén a que se utilizou no Censo de 2001, podemos comparar a distribución das ocupacións na mostra do MSG-04 e na poboación real.

$\mathrm{Na}$ táboa $8^{12}$ vemos a lista de grandes grupos de ocupación que se lles presentou nunha tarxeta aos entrevistados da mostra do MSG-04, para que situasen a súa, e as porcentaxes correspondentes obtidas para cada grupo.

12 Reproduce os datos que figuran na táboa 2.11 do volume II do MSG-04 (páxina 72). 
- Táboa 8. Distribución das ocupacións na mostra do MSG-04

\begin{tabular}{|c|c|}
\hline Ocupacións & $\begin{array}{l}\text { MSG-04 } \\
\%\end{array}$ \\
\hline Profesionais, técnicos e similares & 20,5 \\
\hline Membros do Goberno, altos directivos da Administración pública & \\
\hline e da empresa privada & 10,5 \\
\hline Propietarios e xerentes de hostalaría, comercio e agricultura & 7,9 \\
\hline Cadros medios & 2,4 \\
\hline Capataces e persoal encargado en actividades de servizos persoais & 2,3 \\
\hline Persoal administrativo e similar & 10,5 \\
\hline$\underline{\text { Persoal de servizos }}$ & 13,2 \\
\hline Comerciantes, vendedores e similares & 11,9 \\
\hline Traballadores cualificados e semicualificados & 17,7 \\
\hline Traballadores agrícolas e non cualificados non agrícolas & 2,5 \\
\hline Profesionais das Forzas Armadas & 0,6 \\
\hline
\end{tabular}

Unha mostra ben deseñada non ten por que coincidir co Censo en detalles como a porcentaxe de fontaneiros ou de donos de librarías, pero a representación dos macrogrupos ocupacionais debería tender a coincidir. Iso é o que ocorre aquí no caso das Forzas Armadas: na mostra son o 0,6\% dos ocupados, e na poboación real, conforme ao Censo, son o $0,87 \%$, tan só vinte e sete centésimas de diferenza. Sería completamente normal, tamén, que non aparecese ningún militar na mostra. Pero se saíse un $10 \%$ de militares, quen crería que foi simplemente unha casualidade, produto da mala sorte? Non poderiamos acusar de excesivamente suspicaz a quen sospeitase que algúns dos traballadores de campo deixaron a un lado as follas de ruta e se achegaron aos cuarteis a facer as entrevistas. 
5.1 .

Vexamos o que pasa co primeiro dos grupos da táboa 8, o dos profesionais, técnicos e similares, que forman o $20,5 \%$ de ocupados da mostra ${ }^{13}$. Parecen moitos, a quinta parte dos ocupados. Cantos son conforme ao Censo de 2001, para a poboación galega até 54 anos? Pois só o 10,7\%, a metade dos que hai na mostra do MSG-04. Como se pode apreciar na táboa 9, a representación deste grupo nas cidades é en xeral aceptable, pero no resto hai unha sobrerrepresentación evidente, arredor do triplo en todos os concellos menores de 20000 habitantes e o duplo nos que van de 20001 a 50000 habitantes.

Tendo en conta que nestes concellos se fixeron case catro mil das entrevistas para o MSG-04, e dado que ese grupo profesional é o que menos uso fai do galego, duplicar o seu peso no conxunto da mostra inflúe á baixa nos datos sobre o uso habitual desta lingua, especialmente nos relativos ás vilas e aldeas pequenas ${ }^{14}$.

${ }^{13}$ Segundo os meus cálculos feitos a partir das frecuencias marxinais das táboas do anexo II, serían o 20,7\% (o $21,4 \%$ sen ponderar). Entre as imperfeccións do libro cómpre sinalar a discordancia entre unhas táboas e outras, o que dificulta a verificación dos datos. Por exemplo, se sumamos as profesións na táboa 2.1 da páxina 247, obtemos 6466 ocupados; pero se os sumamos na táboa 3.1 da páxina 253, na que deberían estar todos, obtemos algúns menos, 6454; e se os sumamos a través das diversas mostras parciais por tamaño do municipio, baixan a 6399, contando como cero o dato verdadeiramente disparatado de que dos 885 entrevistados nos concellos que teñen entre 10001 e 20000 habitantes, 445 sexan militares (p. 259); é unha errata, obviamente, pero repetida en todas as táboas sobre este tipo de municipios e imposible de suplir con certeza por parte do lector, debido a esa flutuación no número total. Neses mesmos concellos habería na mostra só 76 mulleres (outra errata) fronte a 440 varóns, cuxa suma obviamente non dá 885. Se tomamos como certo o total de 6339 empregados, e calculamos as porcentaxes ponderadas a partir del, as diferenzas en xeral coas da táboa 8 son tan só de décimas, pero poden chegar a un punto, como no caso do persoal de servizos, no que traballaría o $12,1 \%$ dos ocupados (e non o $13,2 \%$ que figura nos datos publicados). Por outra banda, algunhas das porcentaxes tampouco coinciden coas publicadas no volume primeiro, no que os marxinais das táboas do anexo tiñan porcentaxes en vez de frecuencias.

${ }^{14}$ A importancia da sobrerrepresentación depende non só da contía do exceso, senón do tamaño na poboación do grupo sobrerrepresentado. Por exemplo, duplicar os membros das Forzas Armadas, que é unha ocupación con claro predominio do castelán, tería unha repercusión mínima nos datos xerais sobre o uso das linguas, polo pequeno tamaño do grupo. 
- Táboa 9. Profesionais, técnicos e similares, até os 54 anos (Censo 2001 vs. MSG-04)

\begin{tabular}{lll} 
Profesionais, técnicos e similares & Censo 2001 \% & MSG-04 \% \\
\hline Galicia & 10,7 & 20,5 \\
\hline A Coruña & 17,8 & 23,1 \\
\hline Ferrol & 16,6 & 24,0 \\
\hline Santiago & 21,8 & 26,1 \\
\hline Lugo & 18,5 & 24,8 \\
\hline Ourense & 16,4 & 16,1 \\
\hline Pontevedra & 17,3 & 21,8 \\
\hline Vigo & 14,0 & 22,5 \\
\hline Municipios de 20 001 a 50 000 hab. & 8,4 & 19,1 \\
\hline Municipios de 10001 a 20 000 hab. & 8,3 & 22,3 \\
\hline Municipios de 5001 a 10000 hab. & 6,3 & 20,0 \\
\hline Municipios até 5000 hab. & 5,1 & 15,4
\end{tabular}

\section{2.}

Vaiamos agora ao segundo grupo da táboa 8 (máis atrás), denominado «Membros do Goberno, altos directivos da Administración pública e da empresa privada». A denominación máis parecida a esta no Catálogo Nacional de Ocupacións é a do macrogrupo primeiro: «dirección de las empresas y de las administraciones públicas». Parece o mesmo, pero non o é. A diferenza non é en absoluto trivial, pois no MSG-04 especifícase que se trata de "altos directivos»; no Catálogo, en cambio, inclúense tamén neste grupo os directivos de nivel inferior.

O Censo de 2001 informa de que na poboación de Galicia até os 54 anos de idade só un 8,2\% dos ocupados pertence a este grupo profesional. Na mostra do Mapa, ao tratarse tan só de altos directivos, esperariamos unha porcentaxe bastante menor, pero sucede ao revés: son máis os «altos directivos» na mostra do Mapa ca os directivos de todos os niveis na realidade reflectida no Censo, o que sen dúbida é moi sorprendente.

A sorpresa continúa cando reparamos no grupo seguinte na táboa 8 , o dos «propietarios e xerentes de hostalaría, comercio e agricultura». Son persoal direc- 
tivo? É un asunto opinable, claro está, pero na Clasificación Nacional de Ocupacións, os xerentes están considerados como persoal directivo, dentro do grupo $1^{15}$. Entón, para unha comparación correcta entre o Mapa e o Censo, teremos que desagregar os datos do Censo, e quitar deste grupo ocupacional todos os minidirectivos que xestionan empresas de hostalaría, comercio e agricultura con menos de dez asalariados ou sen ningún, e quedarmos só cos xerentes das empresas de dez ou máis empregados. É algo esaxerado aplicar esta etiqueta de "alto directivo» ao xerente dun restaurante mediano, por exemplo, que dificilmente vai funcionar con menos de dez empregados, entre os da cociña, os de atención ao público e o persoal de limpeza; pero non hai na CNO (nin no Censo) unha categoría que teña un punto de corte máis alto no número de empregados.

Na columna esquerda da táboa 10 pode verse cantos altos directivos hai entre os ocupados da poboación real segundo o Censo de 2001, incluíndo só aqueles que xestionan empresas a partir de dez asalariados.

- Táboa 10. Membros do goberno e altos directivos, até os 54 anos (Censo 2001 vs. MSG-04)

\begin{tabular}{lll} 
Membros do goberno e altos directivos & Censo 2001 \% & MSG-04 \% \\
\hline Galicia & 1,9 & 10,5 \\
\hline A Coruña & 3,7 & 7,1 \\
\hline Ferrol & 2,1 & 14,0 \\
\hline Santiago & 2,9 & 11,3 \\
\hline Lugo & 2,7 & 17,8 \\
\hline Ourense & 2,8 & 17,5 \\
\hline Pontevedra & 2,7 & 22,2 \\
\hline Vigo & 3,0 & 9,2 \\
\hline Municipios de 20001 a 50000 hab. & 1,8 & 9,7 \\
\hline Municipios de 10001 a 20000 hab. & 1,4 & 9,0 \\
\hline Municipios de 5001 a 10000 hab. & 1,0 & 8,0 \\
\hline Municipios até 5000 hab. & 0,8 & 12,7 \\
\hline
\end{tabular}

15 Subgrupos 12, 13 e 1401 para os xerentes de empresas neses tres ramos (hostalaría, comercio e agricultura) con menos de dez asalariados, e os subgrupos 15, 16 e 1701 para os xerentes de empresas sen asalariados. A CNO pódese consultar no portal do Instituto nacional de Estadística: www.ine.es. 
Como vemos, non chegan ao 2\%, mentres que na mostra do Mapa hai o 10,5\%. $\mathrm{E}$, tal como sucedía co grupo dos profesionais, este outro dos directivos, claramente sobrerrepresentado, está entre os que menos usan habitualmente o galego ${ }^{16}$.

A distribución deste grupo profesional nas mostras parciais do MSG-04 é unha sorpresa continuada. $\mathrm{Na}$ cidade de Lugo, case o $18 \%$ dos que traballan fano como altos directivos, e arredor do $22 \%$ en Pontevedra, oito veces máis ca no Censo de poboación. Se lles sumamos a estes de Pontevedra o 21,8\% que serían profesionais e similares, resulta que máis do $40 \%$ dos ocupados nesa cidade terían profesións de alto rango social, un caso posiblemente único no mundo enteiro. $\mathrm{E}$ non menos impresionante é que, na mostra correspondente aos municipios de menos de 5000 habitantes, un $12,7 \%$ dos empregados sexan altos directivos, dezaseis veces máis que na poboación real conforme ao Censo, no que só hai un $0,8 \%$.

\section{3 .}

No sentido contrario ao exposto nos apartados anteriores, os grupos profesionais dos que sabemos que son os que máis usan o galego teñen na mostra do MSG-04 unha representación moi inferior á que lles correspondería conforme ao seu peso na poboación real. O que máis o usa é o penúltimo na táboa 8 (p. 123), o dos traballadores agrícolas e os non cualificados non agrícolas; pero ese grupo ten na mostra tan só a sexta parte do peso que ten na vida real: un 2,5\% na mostra do Mapa fronte ao $14,94 \%$ no Censo de poboación de $2001^{17}$.

\footnotetext{
${ }^{16}$ Mentres que na CNO hai dez macrogrupos ocupacionais, no Mapa hai once, como se pode comprobar na táboa 8 (p. 123). O grupo engadido é precisamente o dos propietarios e xerentes das pequenas empresas do comercio, hostalaría e agricultura. Xa que logo, poderiamos ter procedido doutro xeito: en vez de desagregar o grupo do Censo, poderiamos ter sumado este dos xerentes ao dos altos directivos, co que teriamos un grupo de directivos en xeral, no que traballaría o 18,4 dos ocupados na mostra do MSG-04, fronte ao $8,2 \%$ que nos dá o Censo para a poboación real, até os 54 anos de idade.

${ }^{17}$ No grupo 6 da CNO están comprendidos os traballadores da agricultura e da pesca, e no grupo 9 os non cualificados en xeral. Para o cálculo desta porcentaxe do 14,94\% no Censo de 2001 tomei en conta os traballadores agrícolas e os pecuarios, pero non os da pesca. Xuntei os sectores agrícola e gandeiro porque sospeito que así se fixo na mostra do MSG-04, dada a estreita relación que existe en Galicia entre ambos. Pero se non for como sospeito, se houber neste grupo da mostra só traballadores estritamente agrícolas (ademais dos non cualificados), a desagregación correspondente nos datos do Censo daría un 12,35\%, porcentaxe aínda moi superior ao $2,5 \%$ que hai na mostra. $\mathrm{E}$, ao contrario, no caso de estaren tamén incluídos os traballadores da pesca nese grupo da mostra do MSG-04, a diferenza entre ambos os dous conxuntos de datos (Censo e mostra) sería aínda maior.
} 
Do mesmo xeito que nas outras profesións, o desequilibrio neste sector afecta tamén as mostras parciais. Na correspondente aos municipios de menos de 5000 habitantes, que é onde hai máis ocupados neste sector, temos nos datos do Mapa un 7,5\% de ocupados neste tipo de actividades. Certamente, son máis que nos municipios de maior tamaño; pero son moi poucos comparados cos que hai na poboación real: o $28 \%$ segundo o Censo de 2001, case catro veces máis.

6.

Non me parece que sexa un exceso de suspicacia formular abertamente a pregunta que estamos a calar. A quen se entrevistou? Que sucedeu para que haxa na mostra do MSG-04 tanto universitario, tanto profesional titulado, tanto alto directivo? Ten iso algo que ver con que nos resultados apareza tanto falante de castelán?

Un nesgo tan grande normalmente non debería producirse nunha mostra ben planificada. Se o erro máximo probable para o conxunto de Galicia fose, como se nos di na ficha técnica, do $1,03 \%$ por riba ou por baixo, para un nivel de confianza do $95 \%$, esperariamos que calquera parámetro estatístico relativo á mostra global - por exemplo a porcentaxe dos que teñen estudos universitarios se formulásemos a pregunta só coas opcións «si» ou «non»—- non se apartase máis dun $1,03 \%$ (por riba ou por baixo) da porcentaxe correspondente na poboación real. Se puidésemos tomar infinitas mostras aleatorias do mesmo tamaño que esta, dezanove de cada vinte destas mostras situaríase nese intervalo de confianza, un $1 \%$ por riba ou por baixo do valor real do parámetro da poboación ${ }^{18}$. En circuns-

18 Podemos ser máis precisos na estimación do erro, que é aínda menor, pois o cálculo habitual que se ofrece nas fichas técnicas é unha estimación máxima, que se daría no suposto de que o parámetro real da poboación ante unha pregunta con só dúas opcións de resposta tivese unha distribución do cincuenta por cento en cada unha delas. Neste caso coñecemos moitos destes parámetros reais, porque nolos dá o Censo. Imaxinemos que a pregunta sobre os estudos se formulase dun xeito dicotómico: ten vostede estudos universitarios?, con dúas opcións de resposta, si ou non. O parámetro real da poboación, medido tres anos antes da enquisa (Censo de 2001), indica que o 14,43\% da poboación galega menor de 55 anos ten estudos universitarios. Xa o vimos antes. Pois ben, o erro máximo para un nivel de confianza do $95 \%$ redúcese agora ao $0,73 \%$. Segundo isto, dezanove de cada vinte enquisas que se fixesen cunha mostra do mesmo tamaño ca a do MSG-04 e con selección aleatoria simple dos entrevistados deberían resultar nunha porcentaxe de xente con estudos universitarios situada entre o $13,7 \%$ e o $15,16 \%$. Pero na mostra do MSG-04 temos, como xa vimos, un 31,1\%. 
cricións máis pequenas, concretamente en Pontevedra, non deberiamos esperar desviacións superiores ao 3,7\%.

Estamos simplificando moito, pero esperamos que isto lle dea aos lectores non especialistas unha idea das expectativas, baseadas na teoría da probabilidade, coas que se emprenden este tipo de traballos.

Estamos ante un caso que cae nese 5\% que queda fóra do nivel de confianza? Podería ser, se houbo unha fonda e decidida intervención do demo das sondaxes. Pero é moito máis probable que se fosen acumulando, unha tras outra, desviacións do procedemento aleatorio de selección dos individuos. Se tivesen aparecido demasiados militares, non sería por unha casualidade, senón porque os militares tiveron máis posibilidades de seren seleccionados ca outros individuos. Pois o mesmo pasa se nos aparecen demasiados altos directivos, ou moi poucos labregos.

Neste tipo de traballos non sempre se dan nas fichas técnicas os detalles últimos do proceso de selección, que son habitualmente os que levan a este tipo de nesgo e a mostras que non representan debidamente a poboación real. Temos algunhas sospeitas sobre o que puido pasar pero, sen acceso a eses detalles, pouco se pode dicir. Tamén existen casos de fraude, naturalmente, de maior ou menor entidade, e casos de deficiencias na supervisión e control das rutas. Non estamos asegurando que este sexa un deles porque non o sabemos nin temos forma de sabelo desde fóra do Seminario de Sociolingüística da Real Academia Galega, no que, abofé, deberían terse decatado destes problemas xa nos primeiros días do traballo, e obrar en consecuencia.

7.

Non será necesario, supoño, encarecer a importancia de dispor de bos datos, contrastados e válidos, sobre asuntos desta índole pois, como xa vimos, as nocións cuantitativas son as que apuntalan moitos dos discursos sobre a lingua. E son tamén as que inspiran medidas de planificación e de política lingüística. Por exemplo, o Decreto 124/2007, que regulaba o uso do galego no ensino e cuxa derrogación foi anunciada polo goberno saído das eleccións de marzo de $2009^{19}$, esta-

19 Agora xa derrogado, substituído polo Decreto 79/2010, de plurilingüismo no ensino non universitario. 
blecía no artigo 7.2 que na etapa de educación infantil debería usarse a lingua materna predominante entre o alumnado; e engadía que, para a determinación de cal era esa lingua, deberían terse en conta, entre outros, «os datos achegados polo mapa sociolingüístico de Galicia». Menos mal que di «entre outros», que son os datos estatísticos oficiais e a información achegada polos pais e nais. Pero cales deberían prevalecer no caso de discrepancia entre eles?

Neste caso temos por fortuna outra enquisa da mesma época que o MSG-04, tan só un ano anterior a este, efectuada por xente experta do Instituto Galego de Estatística (IGE). Trátase da «Enquisa sobre as condicións de vida das familias», que se elabora anualmente e que, ademais da información básica que a Administración necesita coñecer con periodicidade anual, inclúe cada ano un módulo específico sobre un tema que require unha periodicidade menor. $\mathrm{O}$ módulo do ano 2003 foi sobre coñecemento e uso do galego. A mostra confórmana unhas 18000 persoas entrevistadas en 6300 fogares $^{20}$.

Os resultados desta enquisa do IGE son moi diferentes dos do MSG-04. Pero, ademais, resulta que, tanto se os analizamos en groso como polo miúdo, son congruentes cos do MSG-92.

\section{1 .}

É especialmente importante a congruencia que se dá nunha variable da que até agora non falamos, a lingua materna ou inicial, aquela en que aprenderon a falar os individuos. Nesta variable non hai cambio intraxeracional (só interxeracional). Os individuos poderán mudar o seu uso preferente das linguas, ter como lingua habitual a que aprenderon máis tarde, ou poden incluso

${ }^{20}$ Exactamente, 18019 en 6304 fogares. No ano 2008, o IGE dedicou de novo un módulo a este tema. Os resultados fixéronse públicos en abril de 2010. Véxase a nota inicial deste relatorio. O novo estudo do IGE comprende unha mostra de 27542 individuos en 10271 vivendas. En xeral, os resultados deste novo estudo son congruentes co razoamento que segue, coas matizacións que se fan nos lugares oportunos. 
cambiar de preferencia máis dunha vez ao longo da súa vida. Pero o dato de cal foi a lingua inicial de cada quen, aquela en que primeiro aprendemos a falar de nenos, é en cada un de nós unha constante que non muda co paso de tempo ${ }^{21}$. Xa que logo, dúas enquisas que comprendan parcialmente a mesma poboación deberían dar porcentaxes semellantes neste dato, nesa parte da poboación que comparten, e sempre que as opcións de resposta sexan as mesmas, naturalmente ${ }^{22}$.

Na táboa 11, na columna da dereita temos os datos de lingua inicial para aqueles enquisados polo IGE que tiñan en 2003 entre trinta e corenta e nove anos. Na da esquerda están os dos enquisados para o Mapa de 1992 que tiñan daquela entre vinte e trinta e nove anos, e que por tanto tiñan en 2003 once anos máis, isto é, entre trinta e un e cincuenta anos ${ }^{23}$.

- Táboa 11. Lingua inicial nunha franxa de idade común (MSG-92 vs. IGE-03)

\begin{tabular}{lll}
$\begin{array}{l}\text { Lingua inicial (na que } \\
\text { aprenderon a falar } \\
\text { cando eran nenos) }\end{array}$ & $\begin{array}{l}\text { MSG-92 } \\
\text { De 31 a 50 anos } \\
\text { (en 2003) \% }\end{array}$ & $\begin{array}{l}\text { IGE-2003 } \\
\text { De 30 a 49 anos } \\
\text { Galego }\end{array}$ \\
\hline Castelán & 37,0 & 47,3 \\
\hline As dúas & 36,1 & 37,5 \\
\hline
\end{tabular}

${ }^{21}$ Pode haber, naturalmente, mudanzas na percepción dun mesmo, por motivos de adaptación a un patrón de desexabilidade social, condicionada polos discursos dominantes. Na Galicia actual, ese tipo de mudanzas deberían repercutir nun aumento dos que se perciben como bilingües iniciais. Pero nada indica que estas mudanzas sexan masivas, até o punto de comprometer seriamente a veracidade da información que achegan os individuos acerca de cal era a lingua que falaban de nenos no fogar. Pode haber tamén (e hai abofé) cambios na composición da poboación; ningún grupo permanece idéntico a si mesmo durante dez anos; algúns marchan, chegan outros de fóra, etc. pero en Galicia non houbo unha presión migratoria moi forte entre 1992 e 2003 que desvirtúe seriamente a estabilidade básica xeral da lingua inicial nunha cohorte de idade.

22 Desafortunadamente, na pregunta sobre lingua inicial do MSG-04 cambiaron as opcións de resposta utilizadas no de 1992, polo que carece de sentido comparar os resultados dos dous mapas.

${ }^{23}$ Este pequeno solapamento dun ano no punto de corte é inevitable se queremos manter a estratificación orixinal por grupos de idade. 
Como ben se pode apreciar, a congruencia é practicamente total. Esa parte da poboación que estaba comprendida nas dúas mostras respondeu o mesmo á pregunta de en que lingua aprenderon a falar primeiro; é o que esperariamos que pasase como mínimo dezanove de cada vinte veces que fixésemos esa pregunta a mostras aleatorias extraídas entre esa parte da poboación.

Gustaríanos insistir nesta congruencia, pois é a que sustenta a fiabilidade dos resultados. Se atopamos esa congruencia alí onde é obrigado que a haxa, porque se trata de variables que non mudan ao longo da vida dos individuos, entón gañan fiabilidade os datos sobre as variables que poden mudar, como o uso preferente dunha ou doutra lingua ${ }^{24}$.

7.2.

Antes diciamos (no apartado 2.6) que os resultados do MSG-04, de seren certos, implicarían non só unha perda interxeracional no uso habitual do galego, senón tamén unha perda intraxeracional, maior aínda ca a primeira. Diciamos tamén que, segundo eses datos aos que non dabamos crédito e que presentamos na táboa 4, un $15 \%$ da poboación comprendida nas dúas mostras ${ }^{25}$ tería abandonado o uso do galego nos doce anos transcorridos entre o MSG-92 e o MSG-04.

Na enquisa do novo MSG-04 hai unha pregunta específica sobre isto, pero lamentablemente os resultados non foron publicados. No estudo do IGE tamén a hai, e resulta, en primeiro lugar, que a parte da poboación que cambiou de lingua habitual nalgún momento da súa vida é ben pequena: arredor do 5\%. En segundo lugar, o cambio non foi unidireccional: houbo quen cambiou para usar máis o castelán, e tamén quen o fixo para usar máis o galego. E, ademais, o saldo entre as dúas direccións favorece lixeiramente o galego, pois deses poucos que cambiaron, algo máis da metade fixérono para pasar a falar habitualmente en galego de modo preferente ou

${ }^{24}$ Os datos do IGE-08 corroboran esta estabilidade, pois na mesma cohorte (a que ten agora entre 35 e 54 anos), hai un 45,5\% que teñen o galego como lingua inicial; os que de nenos aprenderon a falar só en castelán baixan ao $30,2 \%$, e aumentan os que se consideran bilingües iniciais, que son o $21,7 \%$. Non son diferenzas importantes e van na liña do indicado na nota 22.

25 A que tiña en 2004 entre 28 e 54 anos de idade. 
único. O estudo do IGE, entón, confirma que non houbo perda intraxeracional e que incluso houbo unha pequena ganancia (máis ben irrelevante, dun $0,73 \%)^{26}$. Como ese saldo favorable ao galego é moi pequeno e cae dentro da marxe de erro da mostra, podemos afirmar con razoable seguridade que, en xeral, a xente mantivo a súa lingua habitual nos doce anos transcorridos entre os dous mapas. Sendo así as cousas, novamente chegamos á conclusión de que os resultados do novo MSG-04 da RAG están moi lonxe da realidade, pois deberían reflectir ese mantemento na parte da mostra que comparten co MSG-92 ${ }^{27}$. Pero recordemos que foi precisamente aí, nesa parte da mostra, onde vimos ese incrible quince por cento de suposta mudanza por abandono do galego. Se non houbo mudanza en tal proporción, e se a pouca que houbo foi nas dúas direccións cun resultado final neutro (lixeiramente favorable ao galego), deberiamos ter na segunda fila da táboa 4 unha porcentaxe de falantes habituais do galego bastante próxima da que hai na primeira fila.

Son malos os datos do MSG-04? Ou sono os do IGE? Vimos que estes últimos eran plenamente cogruentes cos do MSG-92 no que respecta á lingua inicial. Pero tamén no que se refire á lingua habitual presentan unha congruencia case perfecta (e nada sorprendente, posto que, como acabamos de ver, foron moi poucos os que mudaron a súa lingua habitual).

$\mathrm{Na}$ figura 7 presentamos unha proxección dos datos do MSG-92 ao ano 2003, suprimindo os que terían máis de $84 \operatorname{anos}^{28}$ e atribuído aos máis novos, na columna da esquerda, o resultado que nos ofrece o IGE para o grupo de 5 a 29 anos de idade $^{29}$.

\footnotetext{
${ }^{26}$ Os que cambiaron de lingua foron en total o 5,47\%: o 3,1\% a favor do galego e o 2,37\% a favor do castelán. ${ }^{27}$ Véxase a nota 25.

${ }^{28}$ Como xa vimos, esta supresión ten como finalidade manter o peso dos máis vellos semellante ao do Censo de 2001. Por iso na proxección que vimos antes a doce anos, o límite superior estaba nos 85 anos.

${ }^{29}$ Hai un solapamento de tres anos coa columna seguinte, a dos máis novos do MSG-92. Non é posible axustar a columna do IGE para que conteña só até os 26 anos, porque a institución non fixo públicos os microdatos desa enquisa. Poderiamos evitalo suprimindo a última barra do MSG, pero perderiamos unha información moi importante, que se explica no apartado 8 .
} 
- Figura 7. Proxección a once anos do MSG-92 (con datos do IGE-03 nos máis novos)

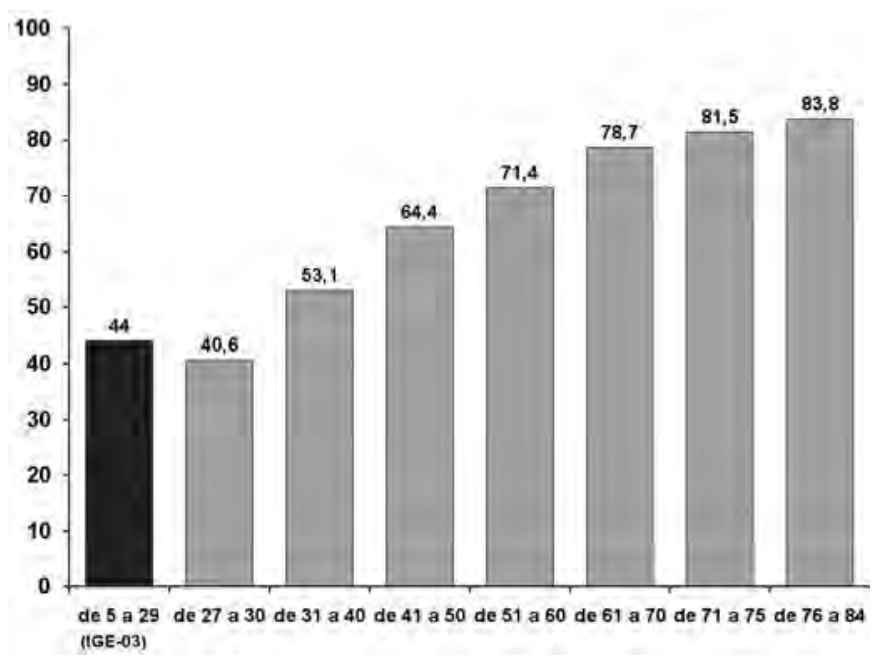

Esta proxección dá para o conxunto de Galicia un 61,5\% de usuarios habituais do galego, que, como mostramos na táboa 12, é o mesmo que obtén o IGE, cunha diferenza tan só de medio punto.

- Táboa 12. Uso habitual das linguas (proxección a 2003 do MSG-92 vs. IGE-03)

\begin{tabular}{lll} 
Lingua habitual & $\begin{array}{l}\text { MSG-92 } \\
(\text { proxección a 2003) } \%\end{array}$ & IGE-2003 \% \\
\hline Galego & 61,5 & 61,0 \\
\hline Castelán & 38,5 & 39,0 \\
\hline
\end{tabular}


Se tomamos en conta tan só un tramo de idade presente nas dúas mostras, como fixemos coa lingua inicial, aparece de novo a semellanza que se recolle na táboa 13, que é precisamente o que esperariamos no caso de non terse producido unha mudanza intraxeracional ${ }^{30}$.

- Táboa 13. Uso habitual das linguas na poboación entre 30 e 50 anos (proxección do MSG-92 vs. IGE-03)

\begin{tabular}{lll} 
Lingua habitual & $\begin{array}{l}\text { MSG-92 } \\
(\text { proxección a 2003) } \%\end{array}$ & IGE-2003\% \\
\hline Galego & 58,4 & 57,2 \\
\hline Castelán & 41,6 & 42,8 \\
\hline
\end{tabular}

8.

Para rematar, botemos unha nova ollada á figura 7. A segunda columna pola esquerda corresponde aos que en 1992 tiñan de dezaseis a dezanove anos, e que tiñan logo en 2003 entre vinte e sete e trinta. A columna primeira da esquerda, que corresponde aos que lles seguen en idade ${ }^{31}$, é un pouco máis alta, o que indica que se rompeu o ritmo descendente na reprodución social do galego, que constituía a principal ameaza para o seu futuro. Pero no MSG-04 dise que entre eses novos mozos hai só un $29,4 \%$ de falantes habituais do galego ${ }^{32}$. Quen ten a razón? Eu non teño dúbidas, aposto polo IGE. Abofé, hai vinte e sete anos que, a partir de datos moi imperfectos, xa observaramos unha desaceleración no ritmo de perda na transmisión inter-

\footnotetext{
${ }^{30}$ Se entrásemos nun maior grao de detalle, veriamos que en realidade si hai unha mudanza pero é doutra clase: hai unha tendencia cara a unha polarización, unha maior radicalización, posta de manifesto no aumento sistemático das opcións monolingües, só en galego ou só en castelán. Na miña opinión, iso, de ser certo, podería indicar máis unha mudanza na percepción de si mesmos ca unha mudanza real no uso; é un tema que haberá que investigar máis polo miúdo. Pero tanta sistematicidade na polarización é sospeitosa, como tamén o é que no IGE-2008 a tendencia desapareza tamén sistematicamente. Tanto a sistematicidade de 2003 como a da súa desaparición en 2008 suxire algunha anomalía nos datos de 2003, imposible de precisar se non se fan públicos os microdatos ou se os autores non o aclaran. Pode tratarse dalgún erro nas fórmulas de ponderación, ou dalgunha diferenza na forma de presentar as opcións de resposta aos entrevistados (ou das dúas cousas).

${ }^{31}$ Véxase a nota 29.

${ }^{32}$ Nun grupo de idade máis reducido, dos 15 aos 24 anos.
} 
xeracional, e manifestabamos a nosa esperanza de que coas medidas de normalización, daquela aínda incipientes, o proceso podería deterse e talvez reverter ${ }^{33}$. Indica este dato do gráfico unha inversión da tendencia? Aínda non o sabemos, pois necesita ser confirmado por outros medios ou por outras enquisas. Pero o que queda claro de todo isto é que non chegou aínda o momento de entoar o de profundis polo galego. Os discursos de defensa e promoción da lingua poden seguir utilizando a noción de lingua maioritaria. Agora ben, non vai ser así para sempre, e non é así en todas as partes. Non é así nas cidades. Isto tamén o sabemos xa desde o MSG-92, e por iso hai que ir ensaiando outros discursos, como xa se está a facer —na miña opinión non sempre con tino-, pero sen esquecer que polo de agora o discurso da maioría, con certa cautela, aínda vale.

${ }^{33}$ Foi unha gran sorpresa para min ver que, anos máis tarde, ese traballo foi interpretado nalgún caso como unha profecía da desaparición do galego nunhas poucas xeracións, atribuíndolle xusto a intención contraria da que eu pretendía transmitir. Espero ter sido máis claro nesta ocasión. 